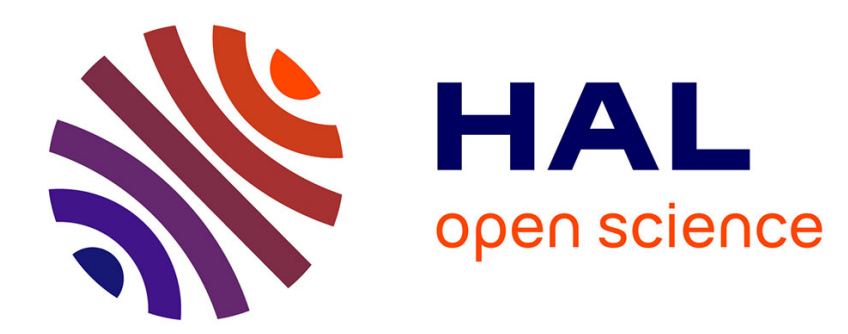

\title{
Cinema, Local Power and the Central State: Agencies in Early Anti-Religious Propaganda in Uzbekistan
}

Cloé Drieu

\section{To cite this version:}

Cloé Drieu. Cinema, Local Power and the Central State: Agencies in Early Anti-Religious Propaganda in Uzbekistan. Welt des Islams, 2010, 50 (3), pp.532 - 563. 10.1163/157006010X545835 . halshs01700280

\section{HAL Id: halshs-01700280 \\ https://shs.hal.science/halshs-01700280}

Submitted on 6 Mar 2018

HAL is a multi-disciplinary open access archive for the deposit and dissemination of scientific research documents, whether they are published or not. The documents may come from teaching and research institutions in France or abroad, or from public or private research centers.
L'archive ouverte pluridisciplinaire HAL, est destinée au dépôt et à la diffusion de documents scientifiques de niveau recherche, publiés ou non, émanant des établissements d'enseignement et de recherche français ou étrangers, des laboratoires publics ou privés. 


\title{
Cinema, Local Power and the Central State: Agencies in Early Anti-Religious Propaganda in Uzbekistan
}

\author{
Cloé Drieu* \\ Paris
}

\begin{abstract}
Lenin, Stalin or Trotsky took early measures to control the cinema in order to transform and enlighten the masses and to implement a proletarian and atheist culture that could replace former norms and homogenize beliefs and values. However, the use of theatre or cinema as a vector for cultural changes was also praisedin a less conceptualised manner-by some Muslim Turkestani élites, who had come to consider, at least as early as 1913, performing and visual arts a mirror that could help society to understand its illnesses and thus to overcome them. The early Soviet period radicalized these conceptions of power and enlightenment toward cinema, which proved a locus for political debates, modernization and agencies that were contended, throughout the 1920s and the 1930s, by Russian Communists and vernacular political or cultural élites in power. Examples of early anti-religious policy as well as film propaganda shed light on this process. In the Soviet context, the analysis of film production permits us to ascertain a complex set of dependencies and agencies between central and local powers, between artists and politics. This article will first focus on a brief institutional history and on the way vernacular élite and ordinary people welcomed the cinématographe in order to underline its peculiar position for our understanding of the cultural changes in the inter-war period. Second, it will examine how officials organised
\end{abstract}

\footnotetext{
* My thanks go to Adeeb Khalid, Alexandre Papas, Juliette Cadiot, Jean-Claude Penrad, Stefan Reichmuth and Paolo Sartori for their valuable comments and their advice. This essay also benefited from the comments of Stéphane A. Dudoignon, when an earlier version of it was presented at his seminar "En islam soviétique: questions, méthodes et connaissances”. I am also very grateful to Justine Landau for her English editing of an early version, and especially to Kaveh Askari for having completed a marathon weekend session finally editing this essay.
} 
anti-religious policy in Uzbekistan, using film in particular. Finally, the article will discuss anti-religious films and their ambivalence until 1937.

\section{Keywords}

Uzbekistan, Soviet, cinema, anti-religious propaganda, film analysis, agency

\section{Introduction}

If we consider, on one hand, Mikhail Bakunin who claimed that the only way to free workers from physical and spiritual debauchery-i.e. tavern and church-is social revolution, and Trotsky on the other hand, who held that cinema can prevent workers from crossing the door of tavern and church, we could argue that cinema is a catalyst for social revolution. ${ }^{1}$ Indeed, this revolution could serve the Soviet policy of modernisation and anti-religious programs. At least, this was the belief of the main Soviet leaders: Lenin, Stalin or Trotsky ${ }^{2}$ took early measures to control the medium in order to transform and enlighten the masses and to implement a proletarian and atheist culture that could replace former norms and homogenize beliefs and values. However, the use of theatre or cinema as a vector for cultural changes was also praised-in a less conceptualised manner-by some Muslim Turkestani élites, who had come to consider, at least as early as 1913, performing and visual arts a mirror that could help society to understand its illnesses and thus

1) Michel Bakounine, Dieu et l'État (Turin: Editions des Mille et une Nuits, 1996) [post mortem first edition: 1882], 17f.; Leon Trotsky, "Vodka, tserkov' i kinematograf", Pravda, 12 July $1923,2$.

2) Lenin's early interest in cinema dates back to his 1907 stay in Finland, V. D. BonchBruevich, "Lenin i kino (po lichnym vospominaniiam)", Kinofront, 13-14 (1927), 3, in Partiia o kino, ed. N. A. Lebedev (Moscow: Goskinoizdat, 1939), 13. For Trotsky, cinema represents a powerful medium of political and social propaganda (for promoting new techniques of production, public health, etc.), A. Goldobin, Kino na territorii SSSR (Moscow: Gosudarstvennoe izdatel'stvo, 1924), 7, 64. Film production was also seen, by Trotsky and later Stalin, as an important source of income that could replace the profit generated by the production and sale of vodka, see S. Krylov, Kino vmesto vodki, K vsesoiuznomu partsoveshchaniiu po voprosam kino (Moscow, Leningrad: Moskovskii Rabochii, 1928), 34; Trotsky, "Vodka, tserkov' i kinematograf", 2. 
to overcome them. ${ }^{3}$ According to Mahmudxo'ja Behbudi, theatre stood for a new type of school (maktab $)^{4}$ — that could work whatever the level of literacy-while for Mirmuhsin "[...] one step toward progress (taraqqi) was done [...]" thanks to the appearance of cinema in the province of Turkistan; the cinématographe was for him a "place for edification" (dār al-'ibrat). ${ }^{5}$ Besides these educational values, cinema was also a perfect symbol of power that had to serve the ruler(s). Isfandiar Khan-or others, such as Sultan Abdülhamit II in the late Ottoman Empire ${ }^{6}$ - had already understood that film, along with photography (or postcards), could serve power and modernization. Khudoibergan Devanov (1879-1938), ${ }^{7}$ whose father was the secretary of the Khivan khan, was the first Central Asian to purchase a photocamera and cinematographic equipment in the late imperial period. He was invited by the khan to set up a film and photo-studio in the palace. ${ }^{8}$

The early Soviet period radicalized these conceptions of power and enlightenment toward cinema, which proved a locus for political debates, modernization and agencies that were contended, throughout the 1920s and the 1930s, by Russian Communists and vernacular political or cultural élites in power. Examples of early anti-religious policy as well as film propaganda' ${ }^{9}$ shed light on this process. In the Soviet context, the analysis of film production permits us to ascertain a complex set of dependencies and agencies between central and local powers,

3) Dilbar Rashidova, "O teatre i sinematografe v dzhadidskom zhurnale 'Oina”, BII [Biblioteka Instituta Iskusstvoznaniia po im. Hamza] M(M) R-28 979/3 pp. 174-179.

4) Mahmudxo'ja Behbudi, “Teatr nadur ?”, Oyna, 10 May 1914, consulted in Oyina (19141915), ed. N. Norqulov, K. Rabbimov (Toshkent: 'Akademiia' nashrioti, 2001), 62ff.

5) Mirmuhsin, "Bizlar ham 'ibrat alailuk", Turkiston Viloyatining Gazeti, 27 July 1914.

6) Mustafa Özen, "Visual representation and propaganda: Early films and postcards in the Ottoman Empire, 1895-1914”, Early Popular Visual Culture, 6 (2008), 145-157.

7) He first produced chronicles and, later, during the Soviet period, made documentaries for the Uzbek State studios. He was probably repressed during the Red Terror, although some historians assert that he was killed because of family dispute.

8) For more details on this period see Olaf Günther, Die dorboz im Ferghanatal: Erkundungen im Alltag und der Geschichte einer Gauklerkultur (Frankfurt am Main: Peter Lang, 2008).

9) We will use the word 'propaganda' in its general meaning: a technique of communication that aimed at obtaining the adhesion to an ideological system and, accordingly behaviour, thanks to psychological means. See the classical study of Jacques Ellul, Propagandes (Paris: Economica, 1990). 
between artists and politics. The nascent film propaganda-and especially that which takes Islam as a main target-is a historical source ${ }^{10}$ that I propose to consider as evidence of the difficulties in implementing the radical changes that took place in the early Soviet period. Indeed, as film propaganda was clearly intended to promote a reshaping of cultural values, it reveals some aspects of the drift in social and cultural representations in the inter-war period.

The study of film discourses seems salutary considering that the period of the 1930s in Uzbekistan is characterised by a relative and growing scarcity of information from archives and press. Was the opening of archives a 'revolution' that could enhance our understandings of the major shifts in the Muslim culture? Of course, this 'revolution' is, for the historians of the Uzbek thirties, particularly frustrating especially for the one who is looking for information that could reflect the society of that time: the archives of the KGB or OGPU as well as those of the Communist Party are closed; noteworthy material available in Central State Archives of Uzbekistan (thereafter TsGARUz) became more sporadic as we move forward towards the thirties; the press ${ }^{11}$ after 1928 was almost fully under political control and became a mouthpiece for the State but not for the citizens. Even there, photographs began to outweigh the printed word. Oral history, still possible to obtain but presumably not for long, constantly distorts the past according to traumatic personal experiences and present contingencies, especially when we deal with political or artistic involvement at the higher levels of the Soviet State. By contrast, silent movies give an alternative voice that could hardly reach us in other ways. I shall first focus on a brief institutional history and on the way vernacular élite and ordinary people welcomed the cinématographe in order to underline its peculiar position for our understanding or the cultural changes in the inter-war period. Second, I shall examine how officials organised anti-religious

10) On films as an historical source see, Marc Ferro, Cinéma et Histoire (Paris: Gallimard, 1993 (re-edition)).

11) Press provides information on film reception—one of the most striking problem-, but those are rare: when they could be found, they predominantly revealed the political film reception, not the social one. We rely on Pravda Vostoka, Komsomolets Vostokal Komsomolets Uzbekistana, Qizil Uzbekiston and Yer Iuzi. 
policy in Uzbekistan, using film in particular. Finally, I shall discuss anti-religious films and their ambivalence until 1937.

\section{Cinema-A Perfect Medium for the Promotion of Cultural Change and Emancipatory Ideas}

To be fully effective, propaganda has to be 'total' (i.e. everywhere, in everyday life), a condition that was not fulfilled during the early Soviet period. Consequently, the terms of "sub-propaganda" or "prepropaganda" 12 are more accurate to describe this phase, when political and ideological efforts began to establish the social, cultural and political control that was eventually achieved by the end of the 1930s. In Soviet Russia, the first step was made on 27 August, 1919, when the Council of People's Commissaries (Sovnarkom) of Soviet Russia (RSFSR) issued a decree that nationalized cinematographic activities, transferring them to the Commissariat of Enlightenment. ${ }^{13}$ In the Autonomous Republic of Turkistan, the same decision was made few months later by the Turkistani Commission (Turkkommissiia). Based on this latter decree of 10 January, 1920, ${ }^{14}$ a first Cinematographic Department (Turkgoskino) was created three days later by the Narkompros. As far as Turkistan was part of the RSFSR, the department was clearly dependent on the Russian decision-making. No studio, within the department, would be created until the territorial delimitation of December 1924.

The 'Great Mute'15 also fascinated the native political élite, especially the Bukharians who thought that cinema could spread new political and social ideas among the population and relay modernist ideas. Cinema was seen as a sign of technical progress, which indeed symbolized modernity and development by appropriating the last achievements of Occidental culture. Therefore, thanks to a cooperation agreement between the Sevzapkino studio in Russia and the Commissariat of Enlightenment of the Republic of Bukhara (BNSR), the first film studios

\footnotetext{
12) Ellul, Propagandes, 10, 42.

13) Decree of the Sovnarkom of RSFSR, signed on 27 August 1919, TsGARUz, f. R-34, op. 1 , d. $594,1.29$.

14) Decree of 13 January 1920, TsGARUz, f. R-34, op. 1, d. 594, 1. 70.

15) Russian bolshoi nemoi; Uzbek buyuk tilsiz.
} 
were inaugurated in Bukhara in April 1924. They were located in the house of Faizulla Khojaev (1896-1938) ${ }^{16}$ himself, close to the fortress in the old city. ${ }^{17}$ The Russo-Bukharan cinematographic society (Bukhkino) had a rather short-lived existence (April-December 1924), but it succeeded in producing the first feature film ever made in the region. The Minaret of Death by V. Viskovskii (1925) was, despite its exoticism, a great success in Uzbekistan and in the Soviet Union and even reached the international film market (Europe and Latin America). ${ }^{18}$

With the national delimitation of 1924, the two organisations (Turkgoskino and Bukhkino) merged to form Uzbekgoskino, which included Sharq Yulduzi (The Star of the Orient) for film-making and Uzbekkino for decision-making, distribution and exhibition. Uzbekgoskino was located in the old madrasa Sheykhantaur. The logo, ${ }^{19}$ used in the $1920 \mathrm{~s}$ only, was characteristic of the organization's hope for cinema. It was to offer liberation from the chains of religion and tradition.

We see here two Muslims of indistinguishable nationality. The one in modern clothing (with a round doppi on his head, a characteristic in movies of the "jadid", and stigmatised as 'bourgeois' and nationalist in the 1930s) is represented in the frame of the (red as well as oriental) star. He raises his hand, throwing a film-roll to free his fellow-countryman, who is tied by the chains of religion and tradition. The latter wears a turban on his head, opens his hands, trying to catch up the 'train of

16) He took part to the revolutionary movement of the Young Bukharians, had important political activity in the government of BNSR and later became the president of the Sovnarkom of the Uzbek SSR. He was arrested on 9 July 1937 and repressed on 13 March 1938.

17) Instructions on the Russo-Bukharian Cinematographic Society (Bukhkino) taken by the Commissariat of Trade and Industry of the BNSR, before 23 September 1924, TsGARUz, f. R-20, op. 1, d. 547, 1. 23f.; Sergei Bratoliubov, Na zare sovetskoi kinematografii (Moscow: Iskusstvo, 1976), 104.

18) A report from the Worker and Peasant Inspection ( $N K R K I)$ quotes that the native audience increased by $40 \%$ when the film was screened, while it usually did not go to see movies, see: report of the People's Commission for the Workers and Farmers' Inspection on cinematographic activities in Uzbekistan, no date [mid-1926], TsGARUz, f. R-95, op. 1, d. 625,1 . 13. The film was sold in 29 countries in 1928, a better result than Eisenstein's Battleship Potemkin, E. Kaufman, "Nashi kino-fil'my za granitsei”, Vechernaia Moskva, 1 June 1928.

19) Unfortunately, the author could not have been identified. However, he was probably from vernacular origin, considering that it has to be read from the right to the left (as the reading of Arabic script). 


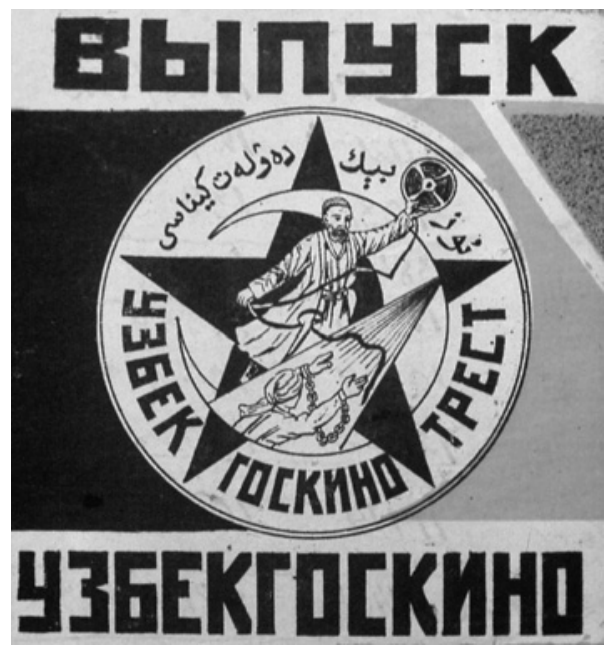

Logo of Uzbegoskino

progress' (the film). But the issue is not sure: will he catch it or not? Whether he will continue to follow the (divine?) light ${ }^{20}$ or will he jump out of this ray? The idea of liberation is also stressed by the fact that the 'modern' Muslim shows his eyes. He seems clever, acting consciously and ready for confrontation. The star, with its five points, shines around inescapably while the crescent, close to a perfect circle, symbolises endless repetition, confinement and blindness. The idea of blindness is also given by the fact that the eyes of the 'old-fashioned' Muslim are not seen. A sense of superiority is created by the vertical composition: the message enclosed in the film-roll is superior to the light itself, the 'modern' man is superior to the 'old-fashioned' one. The verticality, often used in propaganda, insists on a dichotomy between paradise and hell and inverts the religious message. Here religion, which usually leads one to paradise, is subservient to the progressive medium. Film is the means for liberation, it interferes with the light (at the meeting point of the crescent and the red star), which however provides the necessary

20) Alexandre Papas even suggested that this light could be read as 'Muhammadan', symbolising illumination and mystical gnosis. 
luminosity for screening. Indeed, the liberation stems from an intertwining alliance of the red star and the Islamic crescent. ${ }^{21}$

Ordinary people also responded positively to the implementation of cinema. This was the undeniable reaction after the creation of Uzbekgoskino. In an article published in Yer Iuzi, an anonymous writer congratulated the Uzbek SSR because the country was now able to produce "incredible and unheard things" and was capable of "unveiling the mysteries of the Orient". ${ }^{22}$ Accordingly, infatuation for cinema was an essential pre-condition for its acculturative function praised by the élite. Indeed, cinema was per se one of the most fascinating achievements of the beginning of the $20^{\text {th }}$ century: in early $20^{\text {th }}$ century cinema's direct ancestor - the magic lantern-was known to leave a deep impression in audience's mind long after the screenings; ${ }^{23}$ in the early Soviet period, with the help of the dynamo, film could spread all over the country before electrification, especially in rural areas.

For the cultural and political élite, Russian or vernacular, the film proved a perfect means for breaking the chains of slavery (whatever it was: class or gender domination, religion, tradition, etc.) and for fostering protest against 'old-fashioned traditions' and oppression. This was, in substance, the discourse of Serafima Liubimova, who worked many years for the Department of Women's emancipation: ${ }^{24}$

The theatre [and cinema] had to create for the audience a sense of protest against customs and religious laws, which reduce women to a state of cattle. Theatre [and film] must arise, for women, the desire to fight, against the old morality, for their emancipation. On the other hand, it is essential to entice women to the theatre and cinema. How? By organising special performance for women $[\ldots]$ and selecting films and powerful pieces of interest, by offering them discounts on the purchase of tickets [...].

21) The symbol of the crescent and star might also refer to a broader Turkic kinship (cf. the Turkish flag) but in an original manner: the five-pointed star stands strait, and the crescent is reversed in comparison with the flag. It might give ideas of affiliation as well as of differentiation.

22) “Uzbekistāndā kinākartinkachilik bāshlanghichi”, Yer Iuzi, 6 (5 March 1926), 12.

23) N. P. Ostroumov, Sarty, Etnograficheskie materialy (obshchii ocherk) (Tachkent, 1908), 200-205.

24) S. Liubimova, Rabota Partii sredi zhenshchin (Tashkent, Moscow: Turkpechat', 1928), 33. 
"Enticing women" to a dark room with a white curtain (and few chairs) that stood, at that time, for "cinema-theatre", was not so easy, but not impossible. It helped if the projectionists had a good "sense of psychology", a quality that the itinerant projectionists, V. Alexandrov together with Ia. Kalimullin, his assistant of Tatar origin, were proud of. They worked for the International Red Cross $(M O P R)$ and, in 1924, organised itinerant screenings in Tashkent's surroundings.

For the first showings, they were careful to screen only entertainment films, avoiding much politicised ones, so that women could become used to cinema. Their ideas about the use of propaganda in films were clear: ${ }^{25}$

After that [first screenings], accustomed more strongly to the film and developing a real passion for it, cinema will definitely become a common practice. Then we could, with courage and success, use it for our work among women. In this sense, the film is unique because without any noisy struggle or frictions, under the cover of a completely innocent entertainment, it gives the possibility to gather an ever greater mass of women, and to implant and instil imperceptibly, and in very effective shapes, emancipatory ideas.

The report mentioned that some religious leaders in a village eventually agreed - with "the heart grating" (skripiia sredtse) — under the pressure of public opinion, to offer the place of worship as a venue for film screenings. Without any manipulation from the team, it was, in their minds, a "great victory". ${ }^{26}$

Despite the early political support for and openness toward the cinema, and its favorable reception by the audiences, several problems and obstacles arose in the course of time, and Soviet construction turned into bricolage. Even after the decree that nationalized cinematographic activities and created studios in Russia or Central Asia, film activity did not fall under completely centralized political control until 1937, at least in Uzbekistan. Thus it never truly served those ideological purposes to which it had been assigned. Three major economic, political, and institutional factors explain this fact. First, during the early Soviet

25) Report of the Iskra (1924), TsGARUz, f. R-34, op. 1, d. 2559, 1. 8 f.

26) Ibid., 11. 
period, the New Economic Policy (NEP) allowed for a profit-based production system that could be reinvested in film production. Logically, this system paid more attention to audience's tastes than to political requirements. Second, the vernacular cinematographic staff until the thirties lacked basic skills, which mirrored the audience's lack of 'cinematographic education'. Finally, there was a serious need to develop a good network of itinerant or permanent cinema theaters and to train skilful orators for silent movies... not the kind of those who mispronounced 'Soviet stratotegy' instead of 'Soviet strategy'. ${ }^{27}$

\section{Organising and Disorganising Soviet Propaganda Against Islam in Uzbekistan}

If this short institutional history demonstrates the difficulty of establishing State control over film production, the implementation of anti-religious propaganda in Central Asia presents another aspect of this difficulty. Anti-religious propaganda was also subject to fluctuating measures. In Turkistan, the policy of separation of church and state, adopted by the RSFSR as early as January 1918, did not come into effect rapidly. Many acts of violence were committed during the Civil War against religious authorities and places of worship, but they corresponded much more to personal initiatives than to a homogenous and centralised state policy. The first attempt to organise anti-religious policy was made in 1925 with the creation of the "Union of the Godless' (Soiuz bezbozhnikov). One of the major leaders of this policy was E. Iaroslavskii, ${ }^{28}$ who urged for a moderate line, but who felt by 1928 that the time had come to accelerate anti-religious policy. Some Muslim intellectuals, who held communist views, wrote more moderate anti-religious pamphlets and warned not to attack religious sentiments too violently.

At the beginning of the twenties, several initiatives could be assimilated to 'anti-religious propaganda'. For instance, the first Uzbek

27) “Tesno i griazno v kino 'Khiva”, Pravda Vostoka, 23 March 1936, 4.

28) Emil'an Mikhailovich Iaroslavskii (real name: Minei Izarilevich Gubel'man) was born in 1878 and died in 1943. He became a party member in 1898 and founded the journal Bezbozhnik in 1922. 
film-studios Sharq Yulduzi were located within the mosque Ishankul in Shaykhantaur Madrasa ${ }^{29}$ in Tashkent and would remain there for more than forty years. According to a decree of the Central Executive Committee and the Council of People's Commissars taken on 22 December, 1926, buildings were withdrawn from waqf administration and given to Uzbekgoskino. ${ }^{30}$

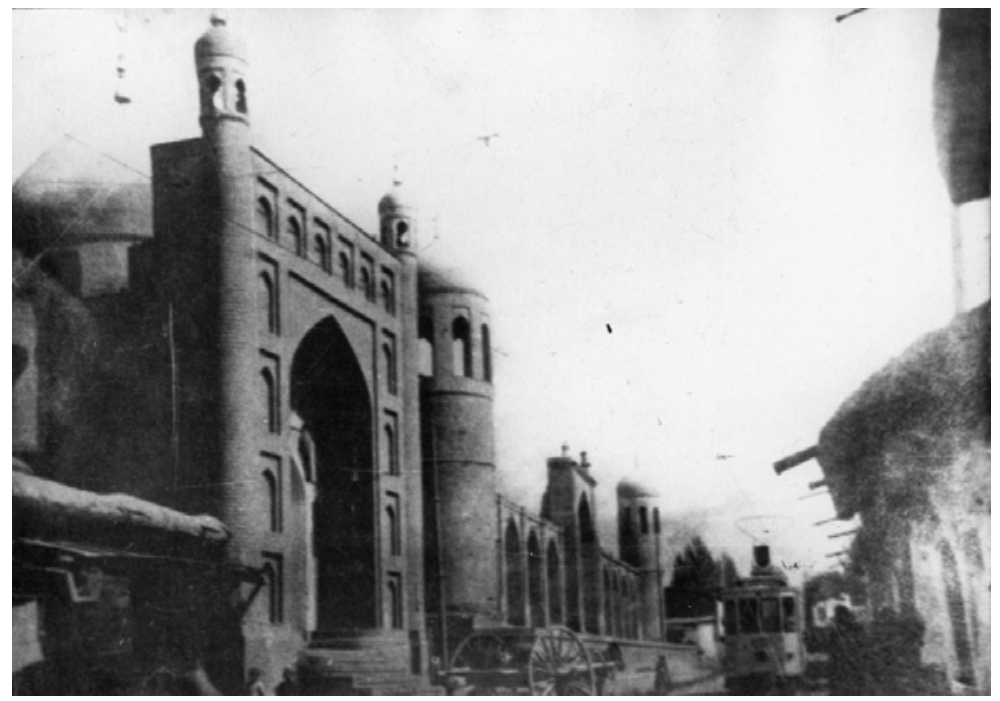

Shaykhantur Madrasa turned into film studio, 1930. Central State Archives of Cinematographic, Photographic and Phonographic Documents of Uzbekistan (thereafter UzRKSOKH) $0-77376$

If the use of worship places for new political, educational or cultural goals should first be understood as necessitated by poor working conditions, it was nonetheless, the first attempt to give new signification to old forms (madrasa, mosques) by overlaying symbolic religious values with new, modern ones. Indeed, the legal policy on religion in 1929 institutionalised a process that was already going on: the transformation

29) Letter of the Narompros to the Sovnarkom, 27 October 1926, TsGARUz, f. R-86, op. 1, d. 2932, 1. 112.

30) Text of the decree, TsGARUz, f. R-86, op. 1, d. 2762, 1. 347. 
of the places of worship into "culture palaces" ${ }^{31}$ It was quite common to see movie theatres located in churches, mosques, even synagogues (in Perm for instance). ${ }^{32}$

In the twenties, the Soviet central state was very far from having the necessary means to implement its policy, and the Union of the Godless had to face many difficulties in its everyday activities. First, some of the reports produced in Uzbekistan admitted that activists lacked qualified staff and a true understanding of Islam. In Muslim regions, anti-religious propaganda was undertaken with a knowledge of Islam essentially based on the one gathered during the imperial period, which was considered by the Russian Communists as deeply insufficient and superficial. ${ }^{33}$ Far different from the challenges to the Eastern Orthodox religion, which was better documented, the development of an antireligious propaganda in Muslim areas was hampered by this lack of knowledge. Muslim atheists bemoaned a total lack of literature on the subject, even in the pages of Bezbozhnik, the leading anti-religious newspaper. ${ }^{34}$ The only exception was a book by a writer named Filippov and published in 2,000 copies. ${ }^{35}$ This was the single reference in Russian before 1927. It was considered satisfying for their work, but anyway a true "Marxist book on Muslim religion" was still missing. ${ }^{36}$ The propaganda effort therefore relied mainly on translation from Russian into native languages, even until the aftermath of the Second World War. ${ }^{37}$ Moreover, Islam was perceived as a more complex religion than Christianity or Judaism because it formed a basis for political and social organisation. It regulated every aspect of the believers' lives, while

31) N. Orleanskii, Zakon o religioznykh ob'edineniiakh RSFSR (Moscow: Izdatel'stvo 'Bezbozhnik', 1930).

32) Kino, 25 (1930), 6.

33) A. Lukachevskii, "Voprosy antireligioznoi propagandy", Revoliutisiia i Kul'tura, 19-20 (1930), 114; Shoshana Keller, "Islam in Soviet Central Asia, 1917-1930: Soviet Policy and the Struggle for Control", Central Asian Survey, 11 (1992), 35.

34) L. Uspenskii, "K voprosu ob izuchenii musul'manstva", Antireligioznik, 7 (1927), 29.

35) It is certainly I. T. Fillipov, Islam v svete istoricheskogo materializma, (Rostov, Don: Sevkavkniga, 1926).

36) Uspenskii, "K voprosu ob izuchenii musul'manstva", 30.

37) See A. Bennigsen, H. Carrère D’Encausse, "La littérature anti-religieuse dans les républiques soviétiques musulmanes", Revue des études islamiques, 1 (1958), 73-85. 
allowing for a possibility of reform. ${ }^{38}$ This was also an argument put forward by Sultan Galiev, who insisted on the difficulty of organising anti-religious propaganda in Muslim areas. For him, Islam had to be considered as a religion as well as a socio-political structure. In this respect, it was quite strong in comparison with other religions since it was, according to his words, the newest one. ${ }^{39}$

Along with these problems, atheists were facing other difficulties of great significance. The social and political background was deeply modified after the Bolsheviks came to power. As a result, religious speech was progressively 'proletarized'. The new sermons were impregnated by common political forms of speech. Henceforth, Baptists brothers could preach that "Jesus Christ was of proletarian origin", that he was "a great socialist" or "the forerunner on the Communist Party". ${ }^{40}$ The representative of the lamaïsts could assert, in 1927, that Buddha, Marx and Lenin were teaching noticeably the same thing. The only "small difference" was that the Communists did not recognise reincarnation. Lenin, "the disciple of the great wise-man Karl Marx", became then the "great reformist of socialism". ${ }^{41}$

Another article mentioned that some 'ulamä' were talking about the "proletarian tendencies" of the Qur'an and that they no longer approached the peasantry or women with "old and fossilised dogmatism". ${ }^{42}$ They softened their speeches towards women for example and could affirm - in the public space ${ }^{43}$ - women's equality with men, which led to an increase in female attendance at mosques. They would also open their mosques to Communist Youth League

38) S. Said Galiev, "Antireligioznaia rabota sredi musul'man”, Antireligioznik, 4 (1929), 65.

39) M. S. Sultan Galiev, "Metody antireligioznoi propagandy sredi musulman", Zhizn' Natsional'nostei, 29 \& 30 (14 December 1921), M. S. Sultan Galiev, Stati (Oxford: Society for Central Asian Studies, 1984), 41f.

40) Lukachevskii, "Voprosy antireligioznoi propagandy", 113.

41) Ibid.

42) Arsharuni, "Antireligioznaia propaganda na Sovetskom Vostoke", Kommunisticheskaia Revoliutsia, 1 January 1929, 73, quoted by Keller, "Islam in Soviet Central Asia", 38.

43) Agitation of the mullah's against the Soviet modernisation was made in private, see Paolo Sartori, "The Tashkent 'Ulamâ' and the Soviet State (1920-1938): A Preliminary Research Note Based on NKVD Documents", Patterns of Transformation In and Around Uzbekistan, ed. P. Sartori, T. Trevisani (Reggio Emilia: Diabasis, 2007), 173. 
(Komsomol) meetings, or authorise the International to be played after a speech ordinarily considered "reactionary" by atheist activists, as it was the case in Marghilan. ${ }^{44}$ Indeed, those who were called the "red Mullahs" continued preaching under the cover of being Bolshevik. Originally from Tatarstan, they would gather funds among Muslim Tatars who were working in important industrial centres. Atheists were complaining: "Identified with the program of our party, Islam stands along with communism, and Muhammad can be considered a political friend of Karl Marx!" 45 Islam 'reformed' in this way could support the construction of socialism. It goes without saying that, in such a context, anti-religious propaganda was particularly complex to organise and the khudosizlar could get a bit lost.

However, even if Russian atheists thought that these speeches were maliciously and deliberately intended to manipulate people, for some Muslim scholars Islam and Communism were not necessarily contradictory. ${ }^{46}$ Gustav Krist, a former Austrian prisoner of war, visited Bukhara in the early twenties and remembered: ${ }^{47}$

You may here see the Red Star of the Soviet or the portraits of Lenin and Khidiralieff [Krist's personal friend, he was chairman of the Central Executive Committee of Turkistan] in queer juxtaposition with the ancient text-books of Shariat Law and commentaries on the Qur'an. The Madrasah Mir Arab is a typical example. The narrow cell of the Imam has shelves along the walls, laden with sacred books in Arabic and Kufic script, above which hangs a poster in Uzbek which screams: 'Proletarians of all Lands Unite!' Few religious teachers in other parts of the world would be able to reconcile two philosophies so diametrically opposed. I ventured in some astonishment to ask how it was possible, and was informed that Bukharan students found not difficulty in

44) "Letter by M. S. Epshtein, Secretary of the Turkestan Communist Party to Central Committee of the Russian Communist Party (Bolshevik) on his mission to Ferghana", 17 March 1923, RGASPI (Russian State Archive of Political and Social History) f. 17, op. 67, d. 202, 11. 220, 224, TsK RKP(b)-VKP(b) i natsional'nyi vopros (1918-1933), ed.

L. C. Gatagova, L. P. Kosheleva, L. A. Rogovaia (Moscow: Rosspen, 2005), 102.

45) Said Galiev, "Antireligioznaia rabota sredi musul'man", 63ff.

46) Adeeb Khalid, Islam after Communism. Religion and Politics in Central Asia (Berkeley, Los Angeles, London: University of California Press, 2007), 17.

47) Gustav Krist, Alone Through the Forbidden Land: Journeys in Disguise through Soviet Central Asia (London: Readers' Union, 1939), $203 \mathrm{f}$. 
keeping the teachings of Lenin and of Muhammad in two separate mental compartments.

Relying on articles published in the native Bolshevik press, Bakhtiyor Babajanov noticed that Islam and Communism were often associated. The use of religious vocabulary or quotation of the Qur'an's verses or of hadith (till 1927-1928) allowed a translation of the new ideas into a rhetoric comprehensible to a large population. ${ }^{48}$ It could be used to appear in line with Islam, with view to a still vivid basmachi movement. The devotion of native Communists to the new régime also provided subject-matter for satirical critics. ${ }^{49}$ Here the case of Azerbaijan can be extended to Central Asia. The Bolsheviks frequently resorted to an Islamic terminology to win the support of 'ulama', who were forced to react. ${ }^{50}$

This situation characterised the twenties, that is before the first important anti-religious campaign throughout the Soviet Union (193031 ), in which cinema had to participate. This campaign was actually part of a large-scale wave of social and economic transformations of unprecedented violence. These included women's emancipation (bujum) which began in $1927,{ }^{51}$ collectivisation, and the violent deportation of wealthy landowners (kulaks, bais) and persons stigmatised as 'nationalist' or 'bourgeois' (the Jadids among others). These measures of social engineering were often a pretext for fighting against the believers

48) Bakhtiar Babajanov, Zhurnal 'Haqiqat' kar zerkalo religioznogo aspekta v ideologii jadidov (Tokyo: NIHU Program Islamic Area Studies, 2007), $44 \mathrm{f}$.

49) Babajanov, Zhurnal 'Haqiqat', 45.

50) Volker Adam, "Why do they cry? Criticisms of Muharram Celebrations in Tsarist and Socialist Azerbaijan", The Twelver Shia in Modern Times: Religious Culture \& Political History, ed. R. Brunner, W. Ende (Leiden, Boston, Köln: Brill, 2001), 128.

51) Hujum is an Arabic word, which means "assault". However, the first term employed by Communists to qualify policy of women emancipation was tajovuz, which means "rape". It could give a real idea of the misunderstanding of local psychology in the implementation of Soviet policy, see Marianne Kamp, The New Woman in Uzbekistan: Islam, Modernity and Unveiling under Communism (Seattle, London: University of Washington Press, 2007), 164. For other works on the policy of emancipation, see Douglas Northrop, Veiled Empire: Gender \& Power in Stalinist Central Asia (Ithaca, London: Cornell University Press, 2004); Chiara De Santi, "Cultural Revolution and Resistance in Uzbekistan during the 1920s: New Perspectives on Woman Question”, Patterns of Transformation, 51-89. 
themselves. ${ }^{52}$ Before this time (in the 1920s), only religious institutions, their endowments (waqf) and the religious or spiritual authorities (mullahs, ishans) were repressed. The physical repression and disappearance of Muslim social structures, a pre-requisite for effective propaganda, ${ }^{53}$ was concurrent with a smoother, more systematic and psychological propaganda. It was supported by a great variety of media. Theatre, radio, music, painting and any other kind of artistic expression were mobilised to create an anti-religious consciousness. ${ }^{54}$ The role of the native cultural élite has to be underlined in the propaganda efforts, at least through films.

During the early Soviet period and owing to the lack of specifically anti-religious movies, certain booklets of film propaganda, intended for the projectionists and political activists, claimed that "all types of films" can suit anti-religious purposes. They 'simply' needed to be accompanied by political speech. A documentary on the first five-year plan or even some American religious films were proposed to fight against "religious obscurantism", as long as they had appropriate accompaniment by an orator. ${ }^{55}$ This reinforces the importance of the oral element in the screening of silent movies while also indicating how difficult the work of the bonimenteur could be. Later on, and especially thanks to the activity of native filmmakers, most of the religious beliefs of the Soviet Union could find a negative representation in movies. ${ }^{56}$

52) Shoshana Keller, To Moscow, not Mecca, The Soviet Campaign Against Islam in Central Asia 1917-1941 (Westport, Conn.: Praeger, 2001), xiv ; Isabelle Ohayon, La sédentarisation des Kazakhs dans l'URSS de Staline, Collectivisation et changement social (1928-1945) (Paris: IFEAC, Maisonneuve \& Larose, 2006), 63; William B. Husband, "Soviet Atheism and Russian Orthodox Strategies of Resistance, 1917-1932", The Journal of Modern History, 70 (1998), 79f.

53) A group which is too well structured can not be reached by propaganda, Ellul, Propagandes, 21.

54) E. Iaroslavskii, "Iskusstvo na sluzhbe u religii i iskusstvo bezbozhe", Antireligioznik, 2 (1929), 7.

55) V. Stepanov, "Kino i antireligioznaia propaganda", Antireligioznik, 5 (1928), 23.

56) Films were made to fight against the practice of pilgrimage (The Host of the Mecca by G. Tasin, 1930), or more generally against Islam (Under the Strength of the Adat by V. Kas'ianov, 1926; The Third Wife of the Mullah by Viskovskii, 1928), against the Shiite ceremony of flagellation (Shakhsei-Vakhsei-We could not find out the name of the filmmaker, ca. 1928), against the yezidi-s, against chamanism (Igdenbu by B. Bek-nazarov, 
As far as Muslim Central Asia is concerned, two types of films directly participated in anti-religious propaganda. First, the strictly speaking 'anti-religious' films that denounced practices and religious authorities as ishas, mullahs or dervishes: Bismillah by Sharifzade, (Azerbaijan, 1925) against muharram, The Fiancée of the Ishan by O. Frelikh (Uzbekistan, 1931) against 'Ishanism'; Ramazan by Nabi Ganiev (Uzbekistan, 1932), a film which supported the anti-religious campaign against fasting; The Emigrant by Kamil Iarmatov (Tadjikistan, 1934); The Living God by D. Vasil'ev (Tadjikistan, 1935) against Ismailism. Second, the films that deal with Muslim women's emancipation: Chachvon by M. Averbakh (Uzbekistan, 1928), Her Right by G. Cherniak (Uzbekistan, 1931), that cannot be discussed in detail here.

\section{Delegitimising Islam: A Double-Edge Weapon?}

By denouncing religious practices and confessions, silent films gave to religious authorities, even if they were shown as depraved old-fashioned and sometimes dangerous practices, a 'locus of existence'. The search for realistic representation, advocated in the press to avoid the exotic and orientalist drift of the films produced in the beginning of the twenties, incited filmmakers to take advantage of religious processions or true rituals. This confers a posteriori a documentary value to the fiction films. Taking advantage of local personages was also motivated by economic reasons: they were paid less than professional actors, they provided authenticity, and they satisfied the curiosity of the spectators as well as of the authorities (an exoticism of a new type) in other local settings. Indeed, religious practices which were quite confidential (a $z i k r$ for instance) or geographically localised (muharram ceremonies, fasting...), began to enter into a broader public sphere, i.e. at the whole Soviet scale, and circulated throughout the Union. Anti-religious films denounced the exaction committed by mullahs, dervishes and other religious authorities, but they eventually offered them a privileged role and a droit de cité.

1930), against Jewish religion (Jewish Happiness by Granovski, 1925), against Catholicism (The Cross and the Mauser by V. Gardin, 1925), against the Svan Christian community in the Caucasus (The Salt of Svanetie by Kalatazov, 1930), etc. 
For the film Chachvon by M. Averbakh (Uzbekistan, 1927), aimed at supporting the policy of women's emancipation, actual dervishes participated in the shooting. In the film, the young heroine Lola was taken by her husband to visit a popular healer (azaimkhon), who had to "hunt" by traditional means the "red devil" (krasnyi diavol) that blows messages of emancipation. According to some memories of the shooting published in the press, the dervishes were "so well entered into their own role" that they had not noticed, after the projectors have been shut down, that the team was yelling "Cut! Cut!" to stop their "holy action" (zikr), which consisted of "convulsive movements, cries, wild rattles, and a possessed dance". ${ }^{57}$ According to the article, only the call of the muezzin could stop the ceremony. Dervishes left the stage to go to the mosque for the evening prayer. In the film The Last Bek by Sabinskii (Uzbekistan, 1930) — a film dedicated to the death of Enver Pasha of which, unfortunately, only archival documents have remained-a mullah agreed to play in the movie. At the end of every scene however, he made ablutions, constantly regretting having dealt with the shaytan. In the film The Fiancée of the Ishan, a loud (jahri) zikr of the Naqshbandiyya was shot.

The commemoration of Huseyn's martyrdom, known in Soviet Union and Turco-Persian world as "shakhsei-vakhsei" (Shāh Hussein, Yāh or Vāh Huseyn) — and particularly denounced by Stalin himself ${ }^{58}$ - , was for example recorded by the camera in the film Bismillah by Sharifzade (Azerbaijan, 1925). The filmmaker insisted on the violence of such a ritual (even though they were afraid of being beaten by the devotees while shooting). Zanjirchi were shown flagellating themselves, or beating their heads with a sword to make their blood flow, echoing what was already denounced in the pre-revolutionary satirical press or literature. ${ }^{59}$

\footnotetext{
57) Insarov-Vaks, "Moskva-Tashkent, Na s'emkakh v Uzbekistane”, Sovetskii Ekran, 4 (1928), 4.

58) "To preserve some of national particularities of the transcausasus Tatars such as selfflagellation during the ceremony of Shakhsei-vakhsei [...] Don't even think about that!", Stalin, Le marxisme et la question nationale (Paris: Edition du Centenaire, 1974), 45.

59) Alexandre Bennigsen, "Mollah Nasreddin et la presse satirique musulmane de Russie avant 1917”, Cahiers du monde russe et soviétique, 3 (1962), 507.
} 
In order to delegitimise religion, these films condemned certain spectacular forms of Islam (Sufism, Ishanism) as a practice of physical violence, abuses (social and sexual), injustice, economic exploitation, etc. In The Fiancée of the Ishan, the representation of Ishanism was particularly negative. It was situated in a land of old and dusty beliefs. The filmmakers insisted on showing old mosques or mausoleums alongside negative intertitles: "In old cities", "Among the dusty mosques", "Dusty words", "There is no god but God"... The mosque was shown as a house of disease, in which superstitious people could only rely on the ishan's intercession with God to solve their problems of illness or sterility. This crowd was shown as widely dehumanised by long shots, women in paranji followed sick men, hobbling, forming thus a wide queue. No one was able to act autonomously... "One prays" and "One awaits with resignation..." "...The miracle".

The most striking scene of delegitimisation of a ishan can be found, without a doubt, in this film: Tursun, a simple-minded husband, who dreamt to have children, thinks that his woman Hakima is sterile. $\mathrm{He}$ decides to bring her to the ishan Abdu Nabi (played by S. Khojaev, $\left.1892-1937^{60}\right)$, full of hope that his spiritual power will achieve the
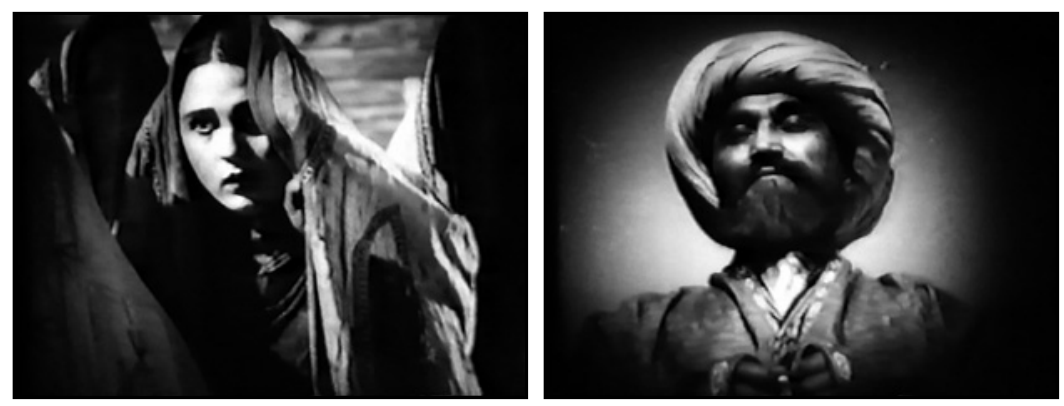

Hakima and the ishan Abdu Nabi, The Fiancée of the Ishan

60) Suleiman Khojaev, whose father was a qori, belongs to the former jadid background. He was an actor at the Turan theater in 1916, and became a filmmaker after various political activities in the 1930s. He made only one long-feature film, Tong Oldidan (1934) on the 1916's uprisings, which was censored. S. Khojaev was emprisoned and repressed in 1937. For more details, see Cloé Drieu, “'Interdit aux Sartes, aux chiens et aux soldats': la Russie coloniale dans le film Tong Oldidan de Suleyman Khodzhaev Uzbekfilm, 1933", Cahier d'Asie centrale, special issue, Le Turkestan russe, une colonie comme les autres?, ed. S. Abashin, S. Gorshenina, 17-18 (2009), 509-539. 
awaited "miracle" of pregnancy. While the couple is awaiting the ishan among a huge crowd, Hakima's veil accidentally falls down and attracts the ishan's attention.

He makes one of his disciples bring the woman to him for consultation, and then sexually abuses her. ${ }^{61}$ The scene of violence is not shown directly. It is suggested by images of Sufis in an ecstatic state, doing a $z i k r$. Their faces are shown in close-up, with faster and faster editing giving the scene. The film juxtaposes practices of $z i k r$ and spiritual ecstasy with those of rape and sexual pleasure.
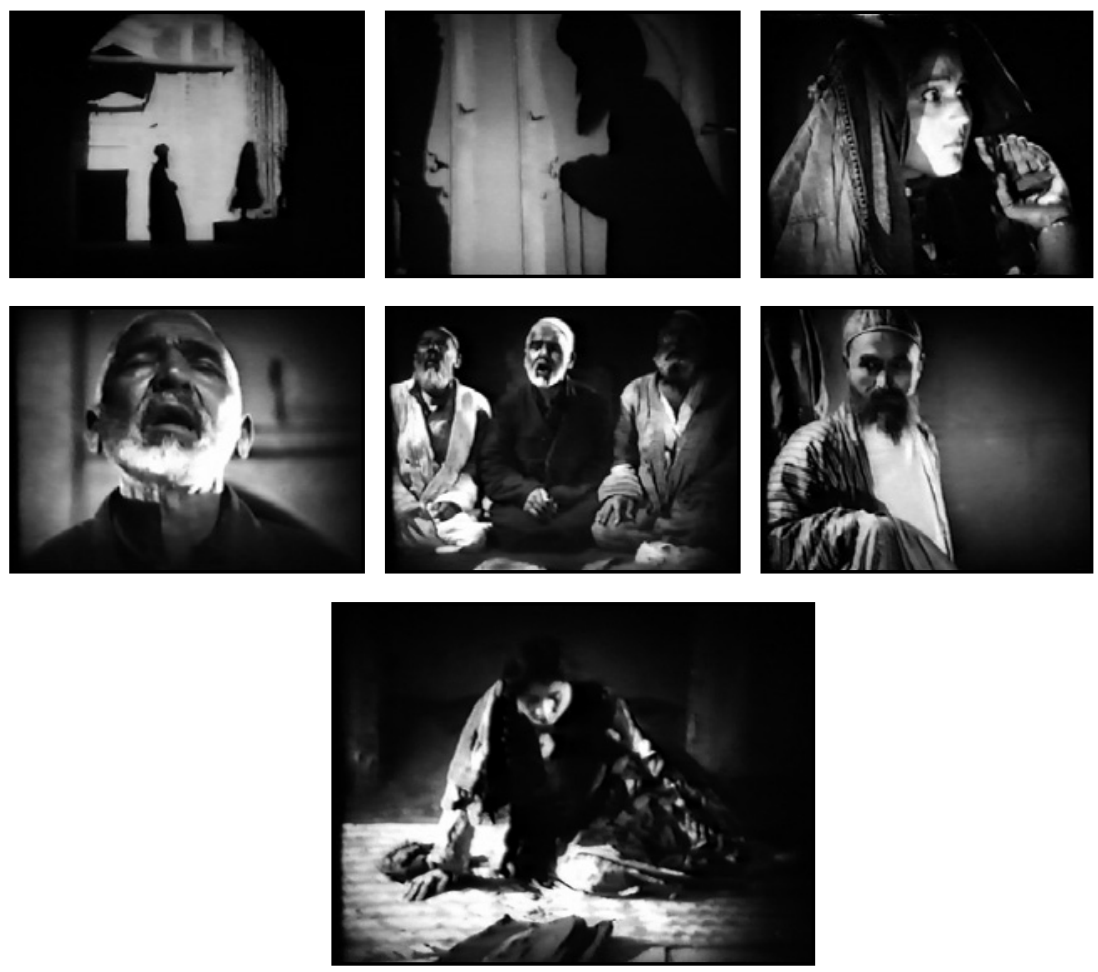

Zikr and rape, The Fiancée of the Ishan

If the intention of the film director was clear, it is more difficult to find out whether the cross-cutting between spiritual ecstasy and sexual vio-

61) The rape was also part of the above-mentioned film Bismillah. 
lation would have been taken in by the local public. In fact, we know that cross-cutting and other editing techniques were generally not well understood at that time as it constituted a rupture in action or temporality, rather than a possible link to a new sense. ${ }^{62}$ But whether or not this advanced editing technique clearly conveyed its intellectual message, the perception of rape and sexual abuse remained clear. Then, as a direct result of this rape, the "miracle so awaited" by Tursun comes true. He becomes the "father" of a girl conceived through this act of violence. The sexual decadence of the ishan is worsened even further by a potentially incestuous relationship. After having seen the young Oiniso few years later, the ishan decides to marry her, without knowing that he is her natural father. Hakima, who tries to oppose this marriage, lets her daughter flee to the Komsomol, the only place she considers safe. When Hakima's husband learns of his daughter's escape, he decides to kill his wife. Eventually, Hakima reveals the truth and the people decide to send the ishan to court. Tursun learns the hard lesson that religion is a lie.

If sexual abuse was used to delegitimise religious authorities, in the case of Ismailism, the economic and capitalist abuses were used to
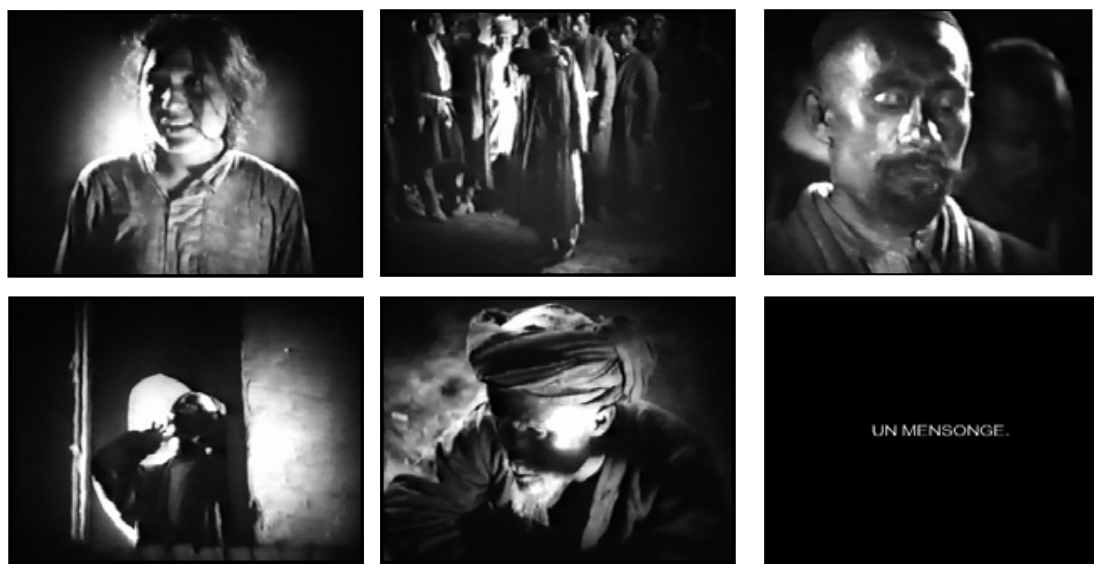

"Religion, a lie" film stills, The Fiancée of the Ishan

62) M. Bunegin, Massovaia kino-rabota v natsional'nykh raionakh (Moscow: Roskino, 1933), 33. 
denounce Aga Khan and his community. The filmmakers of The Living God conveyed a message that gathered the main leitmotivs of Soviet propaganda. Considered by Ismailis the manifestation of God on earth, Aga Khan was denounced as a spiritual fraud, as well as the head of a social and economic organisation. Because of the system of zakat, he represented, in the Marxist dialectic of class-struggle, a perfect capitalist who abuses the poor. For Bolshevik propagandists, Aga Khan sanctified the bourgeoisie, which was a "deification of exploiters' power". ${ }^{63}$ According to Ismaili doctrine the discipline of dissimulation of one's belief (taqiyya) constituted a threat to Soviet power. This practice was also condemned as a factor that could spread or reinforce Ismailism's power. ${ }^{64}$ Finally, he was also the symbol of a double imperialism: he was close to the Tsarist Empire and the Orthodox Church (he visited Orthodox religious authorities in Moscow and Kiev in September 1912), and also harboured strong Anglophile sentiments. ${ }^{65}$

What were the true effects of these movies and this type of propaganda? First of all, one must raise the general question of their original goals. By whom were they formulated and for whom were they designed: the central or the local State? What is the specific cultural background of the filmmakers? For which audience (Muscovite or local) did they create their films? Even if the demarcation of the spheres of influence at work in the production of the films is made difficult because of the limited archival materials, some answers can nonetheless be proposed. In the film Her Right by Cherniak (Uzbekistan, 1931), the subtitle "Thousands of women are still under the influence of Sharia ..." was quickly followed by: "The duty of war of all workers is to involve 1600000 women in the industry." Was it, indeed, a film to free women from religion and help them gain equality with men? Or was it just an attempt to find a surrogate proletariat? The economic and labour finalities seem to take precedence, in films made by Russian filmmakers invited by the film studios or for the official central press, over the development of an anti-religious consciousness. Similarly, the statement

63) S. Imanshtein, “Tov. Stalin i natspolitika partii”, Novyi Vostok, 28 (1930), quoted by M. Kefala, “Antireligioznyi kinodoklad 'Doch' sviatogo”, Antireligioznik, 6 (1931), 36.

64) L. Klimovich, "Ismailizm i ego reaktsionnaia rol”, Antireligioznik, 8 (1937), 35.

65) Ibid., 36. 
published in the anti-religious newspaper Antireligioznik, that had accompanied the film The Fiancée of the Ishan, and helped the orator with explanation, ${ }^{66}$ paid scant attention to anti-religious propaganda and Islam, but placed greater emphasis on the industrialisation and the collectivisation of agriculture. It thus provides an important hint to the priority of the economy and its place in Soviet Union. However, according to a report from the cinema organisation's bureau based in Khorezm, its head urged Uzbekkino to send more films of that kind, because they were appreciated and comprehended by native audience. ${ }^{67}$ As far as The Living God is concerned, it seems that the commercial entertainment potential was stronger than any of its other goals. Interestingly, the film, of 1935, still bears traces of influence from German expressionism in the vein of Fritz Lang.

Accordingly, the true anti-religious aims were sustained by native filmmakers like Sharifzade (Bismillah) and Kamil Iarmatov (The Emigrant). These aims were also sustained by Russian teams like Oleg Frelikh with Suleiman Khojaev (The Fiancée of the Ishan). These filmmakers were more aware of the sociologic determinism of their own people than of other cultures. In their anti-religious propaganda, Muslim intellectuals expressed an anticlericalism and a denunciation of superstitions that was not new. Examples could already be found in the Caucasus, for instance, where the most famous satirical newspaper, Mollah Nasreddin, published in Tiflis, served as a model ${ }^{68}$ and also, a bit later, in Central Asia. In Turkistan, the press was a relay for criticising the sheykh and ishan or for condemning local customs or other rituals. ${ }^{69}$ Secularisation and anti-clerical discourses were already on the Jadid's modernisation agenda before the Bolshevik revolution. ${ }^{70}$ The creation of an Uzbek state, which benefited from cultural autonomy

\footnotetext{
66) Kefala, "Antireligioznyi kinodoklad 'Doch sviatogo”, $92 \mathrm{ff}$.

67) Report, 18 March 1931, TsGARUz, f. R-95, op. 7, d. 950, 1. 63.

68) Bennigsen, "Mollah Nasreddin", 505-520.

69) Sartori , "The Tashkent 'Ulamâ'”, 171.

70) See most of the works of Adeeb Khalid, and especially his, The Politics of Muslim Cultural Reform (Berkeley, Los Angeles, London: University of California Press, 1998); "Nation into History: The Origins of National Historiography in Central Asia", Devout Societies vs Impious States? Transmitting Islamic Learning in Russia, Central Asia and China through the Twentieth Century, ed. S. A. Dudoignon (Berlin: Klaus Schwarz Verlag, 2004), 127-145.
} 
until the mid-1930s, legitimized the native élites to adress the public sphere and to create their own discourse through new means of communication. If brutality, fanatism of the Shiite clergy and the misbehaviour of some ishans were denounced, humour also played an important role in the cinematographic rhetoric. In Bismillah, the Azeri mullah was "carefully taking care every week" of his beard, played backgammon and drank wine with his friend, an Iranian mullah of Reza Shah, another "hero of abnegation". The use of humour in propaganda was underlined by Sultan Galiev, who mentioned that jokes about popes or mullahs had much greater effect that direct attempts at persuasion. ${ }^{71}$

The film Emigrant, made by Kamil Yarmatov in Stalinabad's studios, reveals a rare cinematographic mastery and maturity for his first featurelength film. The film, aimed at influencing the way of life of those who were still doubting the rightness of the new Soviet social and economic way of life. This film was characteristic of a "sociological propaganda", of which effects were not directed toward radical actions or rapid mobilisation but rather intended to influence popular opinion in a long-term perspective. ${ }^{72}$ None of the Islamic authorities represented in the filmmullah, ishan-were directly or negatively attacked. They were represented as lenient old men, repeating the same discourse, "If you are not a good Muslim, your woman will follow the path of debauchery", but also despairing of not being (as the elders) listened to anymore. Indeed, this parallel turns the anti-religious message into a competition of generations. The main character Kamil, played by Kamil Iarmatov himself, decides to grant his father's wish, expressed just before his death. "Go to a country where the faith is strong", to which the mullah adds: "Misfortune will reach the one who does not listen to his father." When misfortune does happen (the harvest is particularly bad and his horse dies), it is not because of Allah's will but because of sabotage perpetrated by a former Soviet citizen, who had flown to an Islamic country and had returned to the Soviet Union to spoil its policy. Kamil, who sees Allah's malediction as a result of not keeping his father's last wish, divorces his increasingly emancipated wife and decides to leave his kolkhoz for a neighbour country (probably Afghanistan) where "Islam

71) Sultan Galiev, "Metody antireligioznoi propagandy”, 47, 50.

72) Ellul, Propagandes, 76. 
is pure". Kamil's travel can also be understood as a travel to the Islamic past. Not long after his new settlement, his first agricultural activities bring a very good harvest until some religious dignitaries come to collect various taxes.
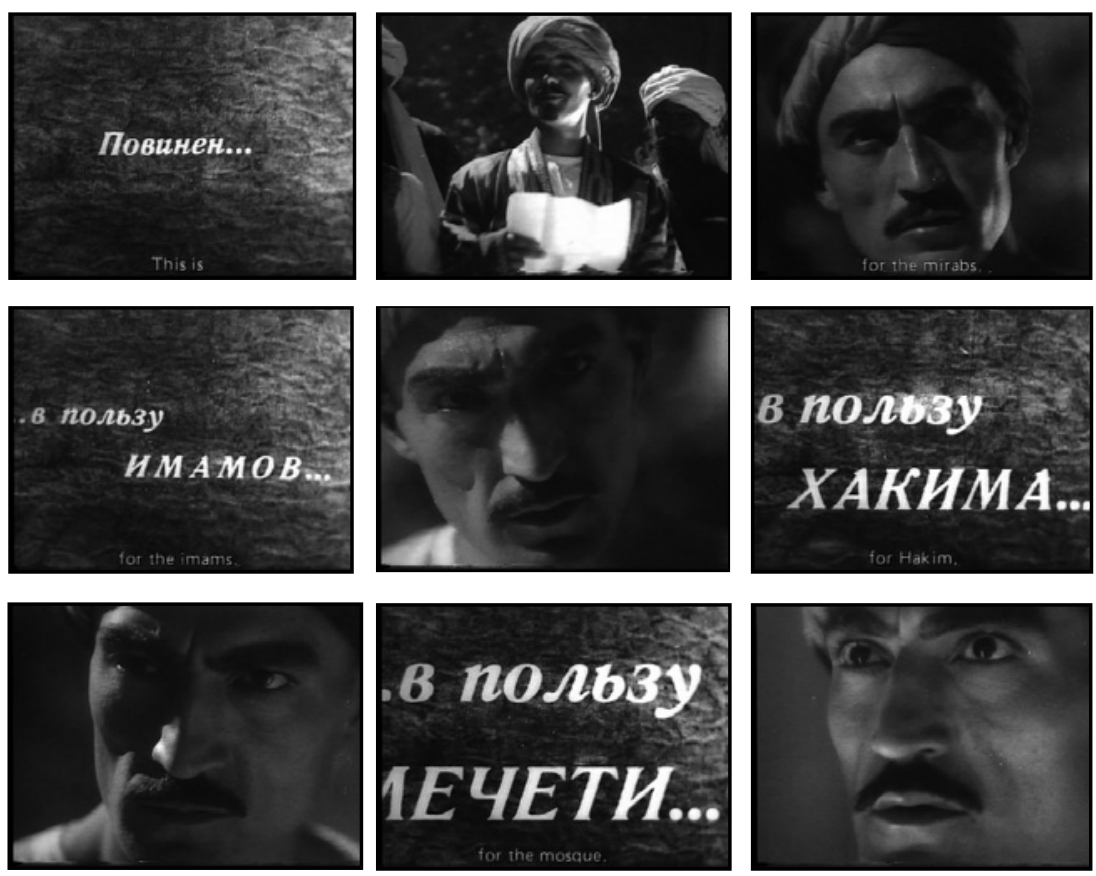

The Emigrant

Then Kamil opens his eyes and discovers that the Islamic world, which he originally thought a paradise, is a place of violence and injustice where work is not valued. Islamic practice is thus denounced in a foreign territory, a way to avoid criticising Soviet Islam. Kamil comes to these conclusions through a process of inner, rationalist thinking. The sentence "Why should a clever man reproduce another's mistake", at the same time a critique of tradition and of the Islamic faith, becomes a leitmotiv that follows Kamil throughout the whole film. By intellect and personal experience, he begins to break the chains of religion as well as the ones of paternal submission, but he still behaves with an irreproachable ethics and morality. Eventually, he returns to his father- 
land and finds his way back to his wife, who regrets that "A clever man should have reproduced other's mistake."

The filmic rhetoric of The Emigrant was particularly smooth, but in other cases images were aggressive and risked being counterproductive. They could incite anger, indifference, or just make the spectator leave the cinema-theatre. This point was noticeably raised by Sultan Galiev, who quoted a case in Tatarstan, where a Bolshevik (mispronounced as bulshaumik) came to a Tatar village to make an anti-religious action. He stepped on the Qur'an shouting "Look, nothing happened to me! That means that this book is not holy, so Allah does not exist." Sultan Galiev concluded that actions like this one could only breed anger. ${ }^{73}$ These kinds of images existed in anti-religious films made in Central Asia: destroying Orthodox bells (Her Right) or portraying Aga Khan and his devotes in a very negative light (The Living God).
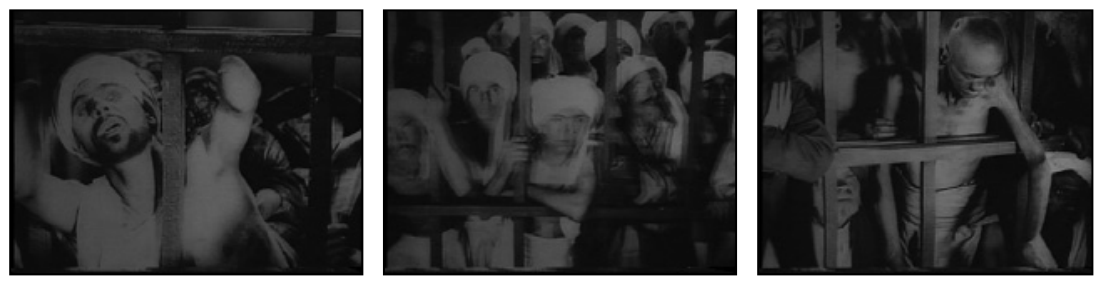

The Living God

According to Said Galiev, "Excessively aggressive campaigns against Islam could also recall the Christian missionary habit against 'the cultural backwardness and religious fanaticism of Muslims'." " Such was the association in the film Chachvon, where an emancipated Muslim woman (Lola) was deified. She was represented in front of a traditional suzane and looked like an icon.

If these kinds of representations are due to Russian Communists or filmmakers who were absolutely not prepared for anti-religious actions

\footnotetext{
73) Sultan Galiev, "Metody antireligioznoi propagandy", 49f. Jacques Ellul noticed the same thing: a message that directly attack a well-established opinion or a stereotype cannot bring any effect, Ellul, Propagandes, 47.

74) Said Galiev, "Antireligioznaia rabota sredi musul'man”, $46 f$.
} 


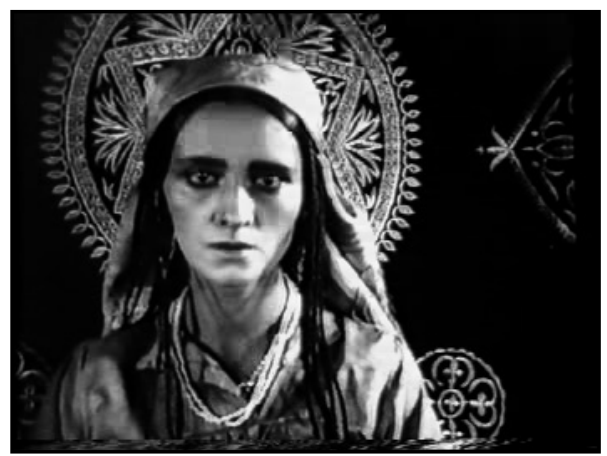

Chachvon

in Muslim areas, Ramazan by Nabi Ganiev, an Uzbek filmmaker, allows us to think about a case of 'counter-propaganda' and indeed resistance to acculturation. This film against fasting probably did not benefit from commercial screenings and seemed to have been only distributed to the kolkhozian audience during the cotton harvest of $1933 .{ }^{75}$ According to the Soviet creed, fasting is presented in the film as an anti-social behaviour. It diminished the yield, generated violence or dispute, and helped mullahs and ishans abuse the poor. But in this film, a bai was drinking wine inside a mosque and eventually became dead-drunk.
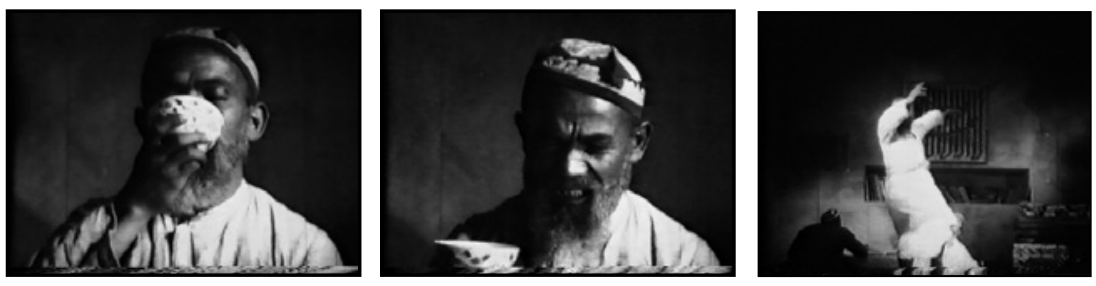

Drunkeness in a mosque, Ramazan

Could such a scene of drunkenness in a holy place be voluntary excessive in order to provoke the opposite sentiment? This 'presumption of propaganda sabotage' can be reinforced by some other ambiguities that

75) No information could have been found in Uzbek newspapers, where usually the films screened in cinema theatres were mentioned. 
punctuated the film. The filmmaker conspicuously engaged in antireligious propaganda also had a small but symbolic role in his movie. He appeared in a scene, where he stood in front of a wide mass of worshipers and initiated the first movements of the collective prayer. Ironically, he made an anti-religious film in which he represented himself praying.
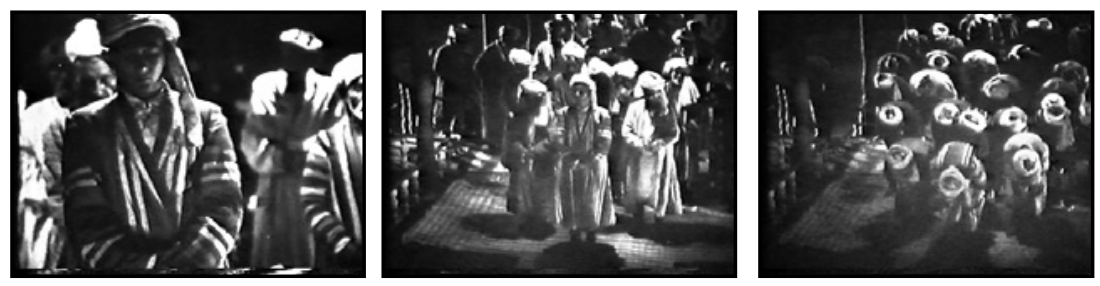

The filmmaker at the collective prayer, Ramazan

To be sure, only a rare few would have been able to recognise him in the scene (probably only those who worked for the film-studio), but this second ambiguity reveals a symbolic 'counter-involvement', an idea that is strengthened by Ramazan's general narrative. Indeed, the film is quite difficult to apprehend: the filmmaker constantly uses mises en abime (stories within the story) that blur the anti-religious discourse and could create contradictory effects. To work, a propaganda film should be simple, direct, and without ambiguity in order to immerse the spectator in the narration. The identification could force him to act as one of the film characters (action, according to Ellul, makes the propaganda effective as far as it then becomes irreversible ${ }^{76}$ ). But in Ramazan, most of the characters have two roles (a positive one and a negative one) that contradict the original message. For instance, one kolkhozian who decided not to fast anymore after 30 years of practice, is discovered, at the end of the film, to be one of the traitors. So, is stopping fasting a treacherous behaviour? Actually, the main character Timur, just like Kamil in Emigrant, behaves strictly. He is honest, refuses to drink alcohol, and he possesses all the qualities a good Muslim could have.

76) Ellul, Propagandes, 41. 

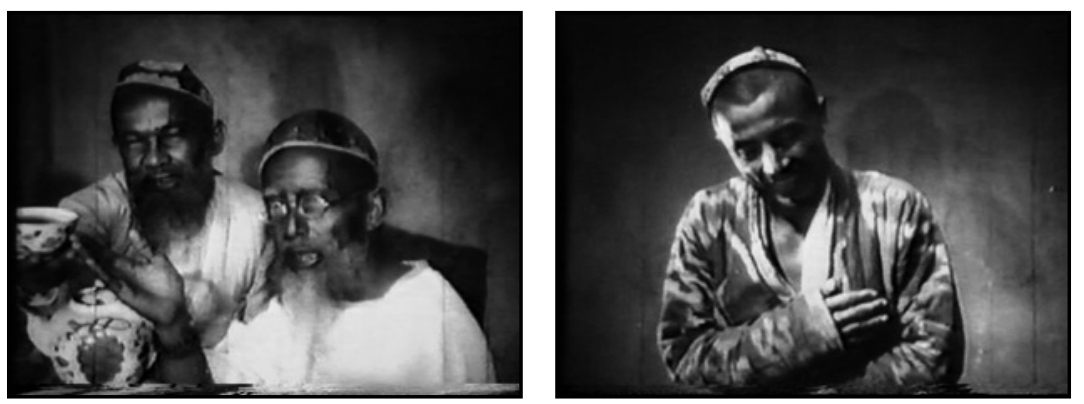

Timur, a good Muslim, Ramazan

Denouncing mullahs and ishan-s, or every kind of religious authorities was inescapable because of political and censorship pressure, but could this denunciation have had a different significance for the Muslim audience? Could not the spectators interpret central characters to be right, and to be good Muslims, without this interpretation being formally expressed by the filmmaker?

\section{Conclusion}

Despite the efforts to produce anti-religious propaganda, religion would not totally disappear from the public sphere in Central Asia, even during the periods of greatest violence in the thirties. Before 1937 the central state could not exert total control, and hence could not completely determine the way anti-religious propaganda was carried out. Since the central state had to reach a compromise with local filmmakers, these could translate ideological demands in their own way. This situation changed only in the late 1930s, when Uzbek or Tajik filmmakers were repressed or put in jail.

While Islam tended to be brutalised and dispossessed of its cultural value, the Bolshevik ideologists tried, by referring to Islam, to legitimise their policy among Muslims. The representation of Bolshevik ideology was full of ideas of messianism. The Bolshevik project, since the beginning of the régime, attempted to replace conceptions and religious beliefs by new secular values in order to transform radically the way of thinking. But at the same time, it borrowed, voluntarily or not, meth- 
ods of communication of religious type. ${ }^{77}$ The representation of religion and Bolshevik power operated on very simple oppositions: the club was opposed to the mosque, the secular order (militia, court) was opposed to spiritual authorities (mullah, ishan, qadis). Factories or clubs became new places of salvation. This dichotomy could be found in almost all the films produced in Uzbekistan. But, in contrast to the films made by native filmmakers, the films made by Russians tended to sacralise Soviet power. The first talking movie produced in Uzbekistan, The Oath by Usoltsev-Garf (Uzbekistan, 1937), was the most emblematic
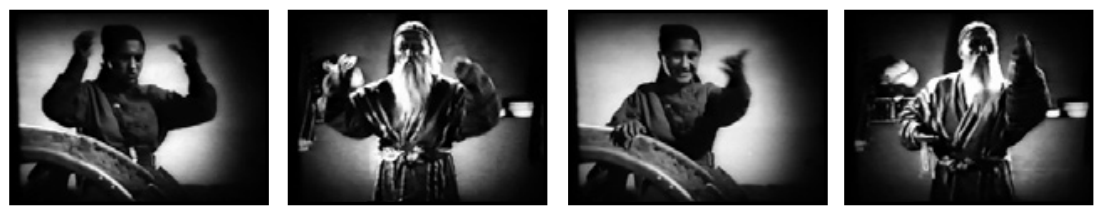

Parallels between the Communist and the ishan, The Fiancée of the Ishan

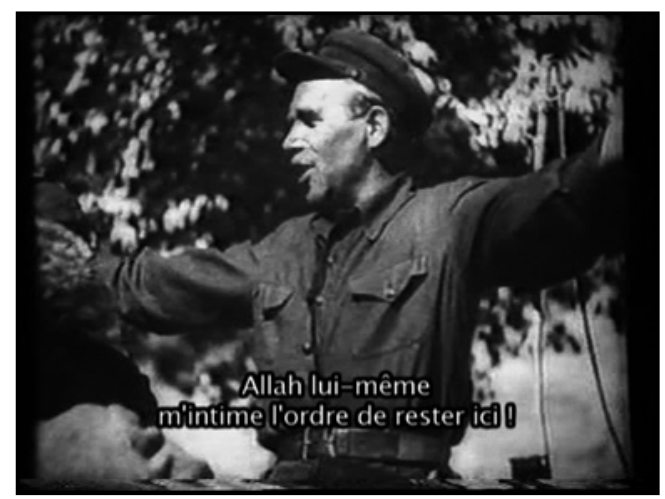

The Oath

\footnotetext{
77) As early as the beginning of Bolshevik régime, the Revolution and the Soviet power were thought and enunciated according to religious references because, see Nina Tumarkin, Lenin Lives! (Cambridge, London: Harvard University Press, 1983); Richard Stites, "Bolshevik Ritual Building in the 1920's", Russia in the Era of NEP, ed. S. Fitzpatrick, A. Rabinowitch, R. Stites (Bloomington, Indianapolis: Indiana University Press, 1991), 297f.; Claudio Sergio Ingerflom, "Communistes contre castrats (1929-1930). Les enjeux d'un conflit" (introduction and notes), V. Volkov, La secte russe des castrats (Paris: Edition Les Belles Lettres, 1995), lx.
} 
example. In the film, Andrei Kravtsov, a Russian Bolshevik (the only Russian in the film), is sent to an Uzbek village by the central power to implement the agrarian reform. He eventually sacrifices himself for the sake of Uzbek peasants. When he arrives to take his position at the peasant council, the muezzin began to call for prayer. Kravstov cries out, opening his arms and turning his face to the sky: "Look! Allah himself orders me to stay here." Another time in the film, the call of the muezzin was used in order to legitimise the announcement of the agrarian reform.

The filmmaker and script-writers, probably in reaction to the failure of direct attacks on Islam, have tried to appropriate the cultural representations of the opposing group (i.e. Islam) and pre-existing attitudes. ${ }^{78}$ On the one hand, it sounds like a failure and a step back toward religion. But on the other hand, exploiting the symbolic capital of religion may have in its own way contributed to the implementation of Soviet ideology in Central Asia, an implementation aided by the native élite who participated in propaganda effort. The Oath proved an important shift in representation, since the native sociological determinism could be understood and used. Indeed, sub-propaganda turned eventually into active propaganda. ${ }^{79}$ Along with the economic, political and social transformations, Soviet experience tends to create a common system of values and homogenized cultural representations that could be significant for everyone who was a Soviet citizen, whatever his/her national, confessional, or ethnic background. In arts, the birth of socialist realism, and its development in the thirties (the film The Oath (1937) are inscribed with their archetypes), tend to achieve this cultural monologism: a vertical, unique, hierarchic practice of creation. ${ }^{80}$ However, the film-production was never all that easy to 'domesticate' after all, and the spectator's reception proved even more difficult to control, as far as the reception of a message acquires significance through interpretation by the viewer. Soviet acculturation tended to homogenise and drastically diminish 'cultural difference' all over Soviet Union, but local agency could not have totally disappeared, unless the native filmmakers

\footnotetext{
78) Ellul, Propagandes, 23, 301ff.

79) Ibid., 42.

80) Régime Robin, Le réalisme socialiste, une esthétique impossible (Paris: Payot, 1986), 20.
} 
were deprived of their right to create. Soviet experience in Central Asia, at the meeting point of the Red Star and the Crescent, generated strange métissages and readjustments, a process whose consequences are still visible today.

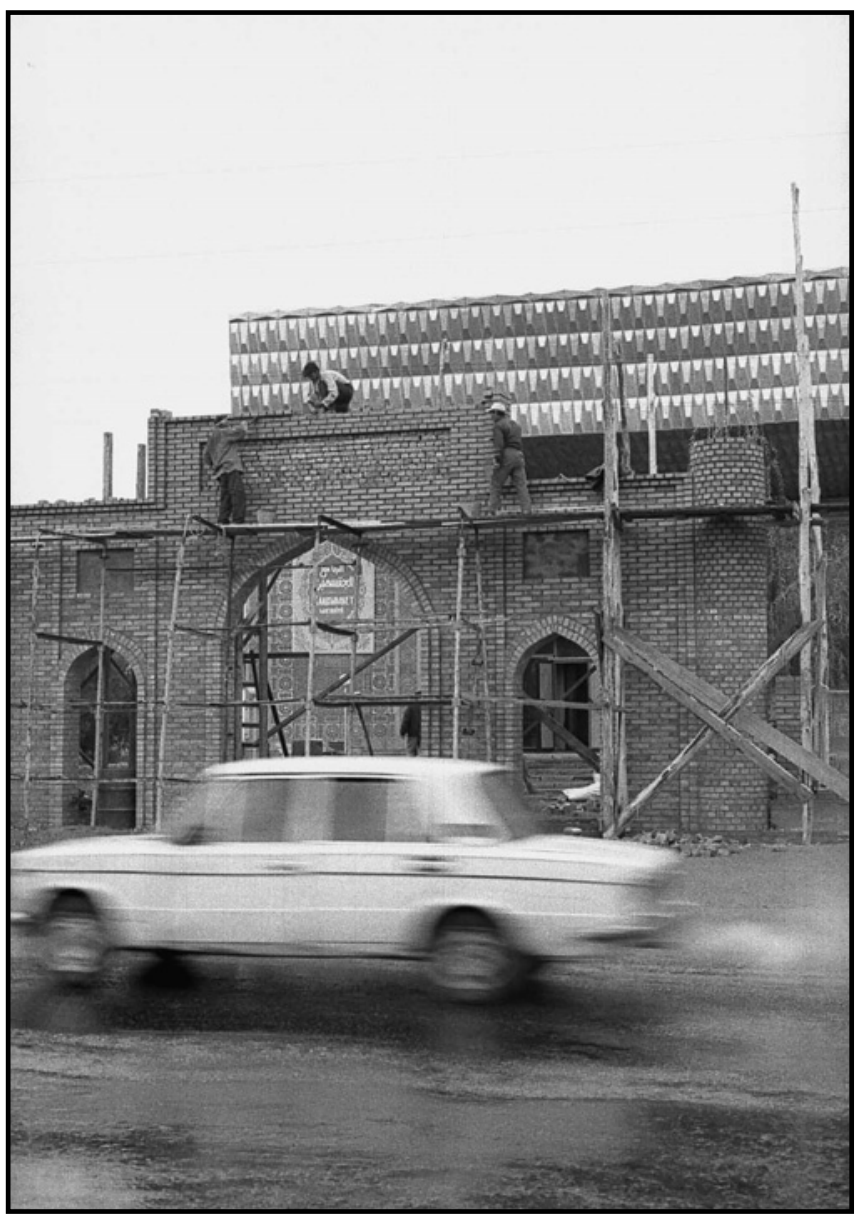

New Islamic faith re-appropriates former Soviet palace of culture: a cinema-theatre transformed into a mosque, Merki (Kazakhstan, 2001) (C) Cloé Drieu 